\title{
INISIASI PENGELOLAAN TANAMAN KUMIS KUCING SEBAGAI ALTERNATIF ANTIHIPERTENSI (INTUISI) DI DESA ANGGRASMANIS KECAMATAN JENAWI KABUPATEN KARANGANYAR
}

\author{
Eka Wisnu Kusuma ${ }^{1 *}$, Devina Ingrid Anggraini ${ }^{2}$, Susilowati $^{2}$ \\ ${ }^{1}$ Prodi S1 Farmasi, Sekolah Tinggi Ilmu Kesehatan Nasional \\ Jl. Yos Sudarso 338 Surakarta 57155, Jawa Tengah \\ ${ }^{2}$ Prodi D3 Farmasi, Sekolah Tinggi Ilmu Kesehatan Nasional \\ Jl. Yos Sudarso 338 Surakarta 57155, Jawa Tengah \\ ${ }^{3}$ Prodi D3 Farmasi, Sekolah Tinggi Ilmu Kesehatan Nasional \\ Jl. Yos Sudarso 338 Surakarta 57155, Jawa Tengah \\ *Email: kusuma.3ka@gmail.com
}

\begin{abstract}
Abstrak
Angka kejadian hipertensi menempati peringkat tertinggi selama tahun 2016 dan kurun waktu 10 tahun terakhir. Hipertensi merupakan faktor resiko utama kasus kardiovaskular. Tujuan dari kegiatan Inisiasi pengelolaan tanaman kumis kucing sebagai alternatif antihipertensi ini adalah untuk memberikan pelatihan dan pengetahuan kepada warga masyarakat tentang pengelolaan tanaman obat tradisional sebagai alternatif antihipertensi. Kegiatan ini dilaksanakan di Desa Anggrasmanis, Kecamatan jenawi, Karanganyar. Rangkaian kegiatan meliputi pengisian pre-test, penyuluhan mengenai penatalaksanaan hipertensi, workshop pembuatan Teh Misella, pelatihan mengenai proses produksi dan keberlangsungan pengelolaan tanaman kumis kucing serta pengisian post-test dan kuisioner. Evaluasi telah dilakukan sesudah kegiatan pengabdian.
\end{abstract}

Kata kunci: Antihipertensi, Jenawi, Kumis Kucing, Missella

\section{PENDAHULUAN}

Indonesia kaya akan keanekaragaman hayati. Kekayaan hayati ini sudah banyak dimanfaatkan oleh masyarakat indonesia untuk mengobati berbagai penyakit misalnya hipertensi. Hipertensi adalah faktor utama penyakit kardiovaskuler yang merupakan penyebab utama kematian yang paling banyak. Hipertensi adalah kondisi dimana seseorang mempunyai tekanan darah diatas normal, yaitu tekanan darah sistolik $\geq 140 \mathrm{mmHg}$ (Chobanian et al., 2003). Berdasarkan Riset Kesehatan Dasar(2007) hipertensi sebesar 6,8\% dimana penyebab kematian ketiga setelah stroke dan tuberkulosis. Pada pasien hipertensi biasanya terdeteksi saat pemeriksaan fisik karena alasan penyakit tertentu, sehingga sering disebut sebagai "silent killer". Gejala-gejala akibat hipertensi, seperti pusing, gangguan penglihatan, dan sakit Kepala (Depkes RI, 2006).

Tanaman yang mempunyai khasiat antihipertensi salah satunya adalah kumis kucing dan rosela. Kumis kucing mengandung senyawa sinensetin dimana senyawanya mempunyai aktivitas inhibisi ACE(Savitri, A. M, 2015). Ekstrak gabungan dari pegagan-kumis kucing-sambiloto memiliki daya inihibisi yang sangat tinggi yakni mencapai nilai $86.99 \%$. Sehingga formula gabungan ini sangat berpotensi untuk dikembangkan sebagai obat antihipertensi (Junaedi, E., Msi, S. P et al., 2013). Kombinasi ekstrak herba seledri, daun kumis kucing dan buah mengkudu (SKM) memiliki aktivitas sebagai penurun tekanan darah pada hewan uji baik pada kondisi normotensi maupun hipertensi (Rumiyati et al., 2016). Tanaman rosella adalah tanaman yang banyak dimanfaatkan untuk pengobatan tradisional, bagian yang sering digunakan adalah bunga. Rosella mempunyai khasiat sebagai antioksidan, antibakteri, anti hipertensi, anti hyperlipidemia, anti diabetes, antinociceptive dan antiinflamasi (Oktaviani, T., \& Megantara, S. 2018).

Tujuan pengabdian kepada masyarakat ini adalah dapat meningkatkan pengetahuan dan ketrampilan warga masyarakat tentang pentingnya pemanfaatan tanaman obat tradisional khususnya didaerah sekitar untuk pengobatan hipertensi.

\section{METODE}

Sasaran dari pengabdian ini adalah ibu-ibu tim PKK Tim penggerak warga desa anggrasmanis kecamatan Jenawi Kabupaten Karanganyar. Bentuk kegiatan pengabdian yaitu melalui penyuluhan 
dan pelatihan Workshop tentang Teh Herbal Celup Antihipertensi dari Kumis Kucing dan Rosella. Metode yang dilakukan melalui ceramah, diskusi dan pelatihan pembuatan sediaan teh herbal. Urutan acara pelaksanaan meliputi registrasi peserta, pengecekan tekanan darah dan pemberian leaflet tentang penyakit hipertensi, dilanjutkan acara penyuluhan dan workshop pembuatan teh herbal celup antihipertensi.

\section{HASIL DAN PEMBAHASAN}

Pengabdian masyarakat ini dilakukan di Desa Anggrasmanis yang terletak diujung wilayah kecamatan jenawi karanganyar dengan luas wilayah 818,978 Ha. Mata pencaharian utama penduduk Anggrasmanis sebagai petani dan buruh tani. Keadaan daerah Desa Anggrasmanis dimana jumlah Puskesmas yang terbatas, letak poliklinik desa yang jauh dari pemukiman penduduk serta topografi pegunungan menyulitkan masyarakat untuk mengakses Sarana kesehatan sebagai alasan kami untuk melaksanakan pengabdian. Acara pengabdian masyarakat yang dilaksanakan dengan berbagai rangkaian kegiatan seperti penyuluhan tentang penyakit hipertensi, penyuluhan tentang sediaan herbal yang dapat digunakan untuk mengontrol hipertensi, serta workshop tentang sediaan Teh untuk alternatif pengobatan hipertensi.

Kegiatan yang dilakukan dengan mendata peserta terlebih dahulu. Data peserta yang dicatat pada saat registrasi yaitu nama, umur, tanda tangan dan tekanan darah peserta. Setelah melakukan registrasi peserta dipersilahkan untuk melakukan cek tekanan darah. Pada saat melakukan registrasi, peserta diberikan kertas pretest yang akan diisi oleh peserta dan brosur berkaitan dengan hipertensi. Setelah itu disampaikan materi mengenai patofisiologi Hipertensi, Mekanisme Hipertensi dan workshop tentang Teh Herbal Celup Antihipertensi dari Kumis Kucing dan Rosella. Dilanjutkkan demo pembuatan teh celup Misella.

Berdasarkan pengamatan pada sesi tanya jawab, masyarakat memberikan tanggapan positif dan antusiasme. Hasil survei menggunakan metode quisioner yang dibagikan pada akhir acara, diperoleh hasil persentase sebesar $63,16 \%$ dari 38 peserta merasa kegiatan pengabdian masyarakat yang dilaksanakan sangat menarik untuk diikuti.

Tabel 1. Hasil kuisioner

\begin{tabular}{cc}
\hline Tingkat ketertarikan & Persentase \\
\hline Sangat menarik & $63,16 \%$ \\
Menarik & $31,58 \%$ \\
Cukup menarik & $5,26 \%$ \\
Kurang menarik & $0,0 \%$ \\
Tidak menarik & $0,0 \%$ \\
\hline
\end{tabular}

Berdasarkan data pada tabel 2, dari hasil pretest dan posttest yang diberikan mengalami peningkatan jawaban benar yang cukup signifikan yaitu untuk hasil pretest yang mendapat nilai A (dapat menjawab semua pertanyaan dengan benar) memiliki persentase sebesar 52,63\%, yang mendapat nilai B (dapat menjawab sebagian dari pertanyaan)yaitu sebesar $34,21 \%$, dan untuk yang mendapat nilai $\mathrm{C}$ (tidak dapat menjawab pertanyaan dengan benar) yaitu sebesar $13,16 \%$. Sedangkan dari hasil posttest diperoleh hasil yang lebih baik yaitu persentase nilai A yang diperoleh sebesar $86,84 \%$, nilai B 13,16\%, dan $0 \%$ untuk nilai C, sehingga dapat dikatakan bahwa penyuluhan maupun workshop yang dilakukan berhasil memberikan pengetahuan kepada masyarakat tentang pengelolaan dan penatalaksanaan hipertensi dan alternatif pengobatannya, acara ini juga menarik minat masyarakat Desa Anggrasmanis.

Tabel 2. Hasil pre-test dan post-test

\begin{tabular}{lccc}
\hline Penyuluhan & \multicolumn{3}{c}{ Tingkat Pengetahuan } \\
\cline { 2 - 4 } & Baik & Cukup & Kurang \\
\hline Sebelum (pretest) & 20 & 13 & 5 \\
\cline { 2 - 4 } & $(52,63 \%)$ & $(34,21 \%)$ & $(13,16 \%)$ \\
\hline $\begin{array}{l}\text { Sesudah } \\
\text { (posttest) }\end{array}$ & 33 & 5 & 0 \\
\hline
\end{tabular}

Pelaksanaan workshop pembuatan teh herbal dilakukan berdasarkan survei lapangan dimana daerah sekitar banyak tumbuh tanaman yang berkhasiat yang belum dimanfaatkan masyarakat sekitar 
karena kurangnya pengetahuan. Manfaat dari pembuatan teh herbal ini adalah dapat meningkatkan nilai guna dan nilai ekonomi kepada masyarakat sekitar dan kedepannya warga masyarakat Anggrasmanis bisa memproduksi teh herbal sendiri.

\section{KESIMPULAN}

Pengabdian kepada masyarakat dilaksanakan kepada ibu-ibu PKK Desa Anggrasmanis, Kecamatan Jenawi, Karanganyar dengan memberikan informasi dan pembudidayaan tanaman kumis kucing sebagai alternatif antihipertensi, dan kemampuan untuk memproduksi secara mandiri sediaan teh celup Misella. Hasil survei menggunakan metode quisioner, diperoleh hasil persentase sebesar $63,16 \%$ dari 38 peserta merasa kegiatan pengabdian masyarakat yang dilaksanakan sangat menarik dan berdampak positif bagi ibu-ibu PKK Desa Anggrasmanis, Kecamatan Jenawi, Karanganyar.

\section{DAFTAR PUSTAKA}

Chobanian, A.V., Bakris, G.L., Black, H.R., Cushman, W.C., Green, L.A., Izzo Jr, J.L., Jones, D.W., Materson, B.J., Oparil, S., Wright Jr, J.T. and Roccella, E.J., 2003. The seventh report of the joint national committee on prevention, detection, evaluation, and treatment of high blood pressure: the JNC 7 report. Jama, 289(19), pp.2560-2571..

Departemen Kesehatan, R.I., 2006. Pharmaceutical care untuk penyakit hipertensi. Jakarta: Direktorat Bina Farmasi Komunitas Dan Klinik Ditjen Bina Kefarmasian Dan Alat Kesehatan, 73.Oktaviani, T., \& Megantara, S. (2018). AKTIVITAS FARMAKOLOGI EKSTRAK ROSELLA (Hibiscus sabdariffa L.). Farmaka, 16(1).

Junaedi, E., Msi, S.P., Yulianti, I.S., Rinata, M.G. and SSi, M., 2013. Hipertensi kandas berkat herbal. FMedia.

Rumiyati, R., Hakim, A.R., Winarti, A.D. and Septia, D.N., ANTIHYPERTENSIVE TESTING OF COMBINATION OF Apium graveolans L., Orthosiphon stamineus Benth., AND Morinda citrifoliaL EXTRACT. ON NORMOTENSIVE AND HYPERTENSIVE SPRAGUE DAWLEY RATS. Majalah Obat Tradisional (Traditional Medicine Journal), 21(3), pp.149-156.

Savitri, A.M., Potensi Ekstrak Air dan Etanol Kumis Kucing, Pegagan, Tempuyung, dan Sambiloto sebagai Antihipertensi serta Profil Senyawa Pencirinya. 